\title{
A collaborative effort of China in combating COVID-19
}

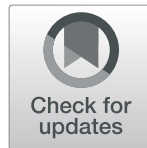

Mohamed S. Bangura ${ }^{1}$, Maria J. Gonzalez ${ }^{1 *}$ D, Nasra M. Ali ${ }^{2}$, Ran Ren ${ }^{3 *}$ and Youlin Qiao ${ }^{1,4^{*}}$

\begin{abstract}
A novel coronavirus (COVID-19) was firstly identified in Wuhan by the end of 2019. China has implemented a series of preventive measures to deter COVID-19 spread and its consequences since the beginning of the epidemic. In China, the expansion of COVID-19 has been slowed down significantly through the effort of all contributors, including governments, nongovernments, and civil society. All collaborators have been actively involved in combating the epidemic, using their respective strengths to play their roles. China has mitigated the number of cases due to the mobilization of the whole society and collaborators joining collective efforts and actions in solidarity to tackle and conquer the virus. To date, China has continued to implement actions to control any resurgence of new cases of COVID-19 and keep its population safe. The people's united effort against the virus has enhanced a great insight into China, and it might serve as a model to the global community in fighting the COVID19 pandemic in terms of coordination, solidarity, decisiveness, and leadership.
\end{abstract}

Keywords: Collaborative effort, COVID-19, Multisectoral, China

\section{Background}

The end of 2019 stunned China with an emerging health outbreak that appalled the Chinese population and the global community. The coronavirus (COVID-19) occurrence in Wuhan, was declared a Public Health Emergency of International concern and it resulted in a rapid rate of transmission [1]. Therefore, the government issued and implemented policies, such as unique mechanisms to track patients with the virus.

Since early April, China has mitigated the expansion of COVID-19 inside the country. Central and local governments took actions to institute several preventive measures to deter COVID-19 spread and consequences [2]. The citizens also played a role by following the regulations and being committed to the measures implemented. Thus, the control of the outbreak has been achieved through the effort of all collaborators. As the virus spread globally in a

\footnotetext{
*Correspondence: mjgonzalez.mendez@gmail.com; Renran99@163.com; qiaoy@cicams.ac.cn

'School of Public Health, Dalian Medical University, Dalian 116044, China ${ }^{3}$ Global Health Research Center, Dalian Medical University, Dalian 116044, China

Full list of author information is available at the end of the article
}

short time, changing into a pandemic emergency, it raised concern over how developing countries would take action to control the pandemic. This commentary aims to demonstrate China's collaborative efforts in controlling the spread of COVID-19 and share practices that can be helpful for the global community.

\section{Actions of government authorities}

As a first measure, the government locked down Wuhan and encouraged people to shut down their businesses and daily activities, staying indoors to contain the spread. Local travels and flights were banned. When the number of cases started to increase in China, other cities also closed access from other residents entering to keep their citizens safe. Social activities and meetings decreased since social distancing measures were implemented in the whole country, including canceling sporting activities and closing up theaters, bars, restaurants, malls, among other places. In addition, such a massive lockdown system in other cities resulted in putting considerable millions of people in a nation-wide quarantine and yielded a beneficial outcome towards combating against the virus [3]. To address the challenge of a shortage of hospital beds for

(c) The Author(s). 2020 Open Access This article is licensed under a Creative Commons Attribution 4.0 International License, which permits use, sharing, adaptation, distribution and reproduction in any medium or format, as long as you give appropriate credit to the original author(s) and the source, provide a link to the Creative Commons licence, and indicate if changes were made. The images or other third party material in this article are included in the article's Creative Commons licence, unless indicated otherwise in a credit line to the material. If material is not included in the article's Creative Commons licence and your intended use is not permitted by statutory regulation or exceeds the permitted use, you will need to obtain permission directly from the copyright holder. To view a copy of this licence, visit http://creativecommons.org/licenses/by/4.0/. 
infected patients, the government rapidly implemented a policy for building temporary hospitals in Wuhan. Two notable hospitals, the 1000-bed Huo Shen Shan Hospital and the 1600-bed Lei Shen Shan Hospital, were built within ten days [3].

\section{Actions of schools and students}

Academic institutions took preventive actions in extending the winter vacation for all students. Those living on campus, have been restricted from going out, and the universities provide them with food, masks, and other necessary supplies. Moreover, the students adhere to control measures and support one another to manage their lives. In the beginning of the pandemic, leaders were formed to monitor compliance in the dormitories, such as checking the body temperature of every student. Most importantly, psychological counseling service has been available in most universities to deal with the panic of the outbreak. As of August 29th, most schools and universities remain closed, and many of them have implemented online classes and live-stream teaching to continue education from a distance.

\section{The dedication and actions of healthcare workers}

Healthcare workers have been fighting on the front line to provide treatment for infected people, while providing residents with anti-epidemic preventive care, disinfection, publicity, and education. Around 42,600 healthcare professionals from all over China were sent to the center of the outbreak in Wuhan to collaborate with the local healthcare workers in combating the epidemic [4]. In addition, the outbreak demanded a rapid and effective response, which led to the intensive and immediate training of doctors, nurses, and other medical staff from different specialties for combating the disease. Furthermore, the medics treating infected patients in isolation wards and the intensive care unit in Wuhan were available $24 \mathrm{~h}$ a day, and many of them abandoned their personal activities and families to answer the call of this national service [5]. Moreover, as the pandemic keeps ravaging other countries, Chinese medical experts continue being committed to controlling the disease, and they are sharing their experiences with other front-liners abroad, either via video platforms or traveling overseas to directly assist in medical care.

\section{Actions of enterprises}

A corporate response to the outbreak focused on supply chain logistics because it is essential in a crisis to ensure the availability of enough supply of materials, including surgical masks, disinfectants, and protective suits for the front-line medical workers. Corporations, including Alibaba, Bank of China, ByteDance, and others donated volumes of healthcare gears and other supplies to the affected areas. Manufacturer companies set up makeshift assembly lines to produce additional medical supplies [6]. In addition, Huawei and China Telecom set up a 5G-enabled remote video diagnostic center, enabling medics to conduct remote online consultations with potential patients. Companies like Alibaba, Tencent, Baidu, ZTE, JD.com, and iFLYEK all implemented technologies as big data in medical services [6]. Furthermore, Information, Communications, and Technology (ICT) have been employed to tackle the epidemic, such as online epidemic information dissemination platforms, Artificial Intelligence (AI), temperature monitoring, and consultation platforms, AI-assisted radiological image interpretation, and intervention recommendations, big data analytics for epidemic prevention and control, supercomputing for vaccine and drug development, and 5Gbased robotics and infrastructure [7].

\section{Actions of scientists and scholars}

The Scientific Community in China, in collaboration with other countries, published and analyzed genomes of the causative agent of COVID-19 and concluded that it might have originated from bats [8]. China has published several clinical guidance manuals and prevention Handbooks in Chinese and English, to collaborate with the global governance of the epidemic. The scientific research team of Shanghai Jiaotong University has provided strong technical support for the release of the first new coronavirus detection kit in China through the application of nanometer magnetic carriers developed over several years [9]. Moreover, the Chinese and international scientists are working rapidly on developing a vaccine against COVID19 [10].

\section{Actions of the community}

As the most grass-roots organization in government, community works monitored residents for signs of illness, screening them for treatment and quarantine, providing food and daily necessities, and bolstering residential checkpoints to guard outsiders who might bring in the virus. The crucial action for citizens was the improvement in personal protection, encouraging people to cover their mouth and nose while coughing or sneezing, avoiding public spitting, regular hand hygiene with water and soap or alcohol-based sanitizer, and wearing face masks to go out, which was mandatory for all inhabitants. Moreover, numerous volunteers assisted in providing enhanced communications and protective strategies for further containment. Actionable information and detailed procedures were shared at the entrance of communities to ensure the health of the population, especially vulnerable people most at risk such as elders. Some of these actionable information and detailed procedures included self-health improvement, self-protection, disease identification, and guidance for help-seeking if needed. These containment 
measures were only effective due to the collective compliance of the citizens.

\section{Actions implemented after revoking the lockdown}

Some new measures have been implemented; residents have to show an application code that will indicate their virus-free status before entering public buildings and hospitals that will disclose the health condition and whereabouts for the last 14 days. At the end of August, 2020 schools and universities across the country started to reopen with caution and strict preventive measures, including disinfectant chambers, body temperature checking, sanitizing daily utilities, and a proper social distancing in the classrooms. Many people have returned to work, and most of the provinces have asked their workers to perform a nucleic acid test to ensure their virus-free condition. On the other hand, to avoid imported cases, Chinese provinces and cities implemented different quarantine policies, such as quarantining travelers from overseas in designated hotels. In addition, since the end of March, the entry of foreign nationals has been temporarily suspended.

\section{Implications of the actions taken by all levels in China}

China has slowed down and controlled the spreading of the virus inside the country due to the mobilization of the whole society joining collective efforts and actions in solidarity to conquer the virus. It is essential to point out that the Chinese whole-of-government approach and social mobilization system are the necessary guarantees for controlling the pandemic. The sense of a community with a shared goal reinforces the joint effort against the epidemic in China. It is with a strong conviction that the people's united effort against the virus has enhanced a great insight into China, and it might serve as a model to the global community.

\section{Abbreviations}

COVID-19: Coronavirus Disease 2019; ICT: Information Communication

Technologies; Al: Artificial Intelligence

\section{Authors' contributions}

Mohamed S. Bangura, Maria J. Gonzalez, and Nasra M. Ali drafted the original manuscript. Ren R. and Youlin Qiao revised the manuscript for advanced suggestions. The authors read and approved the final manuscript.

\section{Funding}

Not applicable.

Availability of data and materials

Not applicable.

Ethics approval and consent to participate

Not applicable.

\section{Consent for publication}

The authors all agreed on the publication of this manuscript.
Competing interests

The authors declare that they have no competing interests.

\section{Author details}

${ }^{1}$ School of Public Health, Dalian Medical University, Dalian 116044, China. ${ }^{2}$ Dalian Maternal and Child Health Hospital, Dalian 116033, China. ${ }^{3} \mathrm{Global}$ Health Research Center, Dalian Medical University, Dalian 116044, China. ${ }^{4}$ Department of Cancer Epidemiology, National Cancer Center /Cancer Hospital, Chinese Academy of Medical Sciences and Peking Union Medical College, Beijing 10002, China.

Received: 30 March 2020 Accepted: 20 October 2020

Published online: 11 November 2020

References

1. Carlos WG, Dela Cruz CS, Cao B, Pasnick S, Jamil S. Novel wuhan (2019nCoV) coronavirus. Am J Respir Crit Care Med. 2020;201(4):P7-8. https://doi. org/10.1164/rccm.2014P7.

2. Azman AS, Luquero FJ. From China: hope and lessons for COVID-19 control. Lancet Infect Dis. 2020. https://doi.org/10.1016/s1473-3099(20)30264-4.

3. Kupferschmidt K, Cohen J. Can China's COVID-19 strategy work elsewhere? Science. 2020;367:1061-2. https://doi.org/10.1126/science.367.6482.1061.

4. Xiaodong W, Yong W. (2020, February 27). Entire nation mobilizes to help Wuhan. Retrieved April 8, 2020, from https://www.chinadaily.com.cn/a/202 002/27/WS5e571e90a31012821727aae0.html. Accessed 8 Apr 2020.

5. Kun L, Zhang Y. (2020, February 12). Medical staff in Wuhan works 24/7 Chinadaily.com.cn. Retrieved March 24, 2020, from https://www.chinadaily. com.cn/a/202002/12/WS5e441722a31012821727716c.html. Accessed 24 Mar 2020.

6. Aikman D, Chan A. (2020, February 20). Five ways Chinese companies are responding to coronavirus. Retrieved March 15, 2020, from https://www. weforum.org/agenda/2020/02/coronavirus-chinese-companies-response/. Accessed 15 Mar 2020.

7. A Decisive Stage for China's Fight against COVID-19 Epidemic. (2020, February 21). Retrieved March 11, 2020, from http://ee.china-embassy.org/ eng/dssghd/t1748005.htm. Accessed 11 Mar 2020.

8. Zhou P, Yang $X$, Wang $X$, et al. A pneumonia outbreak associated with a new coronavirus of probable bat origin. Nature. 2020;579:270-3. https://doi. org/10.1038/s41586-020-2012-7.

9. CNA. China Embarks On Clinical Trial For COVID-19 Vaccine (2020, March 22). Retrieved March 23, 2020, from https://www.channelnewsasia.com/ news/asia/covid-19-coronavirus-china-vaccine-clinical-trial-12565178. Accessed 23 Mar 2020.

10. Wang C, Cheng Z, Yue XG, McAleer M. Risk management of COVID-19 by universities in China. J. Risk Financial Manag. 2020;13:36. https://doi.org/10. 3390/jrfm13020036.
Ready to submit your research? Choose BMC and benefit from:

- fast, convenient online submission

- thorough peer review by experienced researchers in your field

- rapid publication on acceptance

- support for research data, including large and complex data types

- gold Open Access which fosters wider collaboration and increased citations

- maximum visibility for your research: over $100 \mathrm{M}$ website views per year

At BMC, research is always in progress.

Learn more biomedcentral.com/submissions 